\title{
Molecular diagnosis of cytomegalovirus, Epstein-Barr virus and Herpes virus 6 among blood donors in Ouagadougou, Burkina Faso
}

\author{
Lassina Traore*, Issoufou Tao, Cyrille Bisseye, Florencia Djigma, Djénéba Ouermi, Theodora Zohoncon, \\ Tegwindé Rebecca Compaoré, Birama Diarra, Maleki Asshi, Jacques Simpore
}

From International Symposium HIV and Emerging Infectious Diseases 2014

Marseille, France. 21-23 May 2013

\section{Introduction}

This study focuses on three herpes viruses, including EBV, CMV and HHV -6. Our study aims to determine the prevalence of these viruses in blood donors in Ouagadougou.

\section{Material and methods}

The study included 198 blood donors. We extracted DNA, using DNA extraction kit -Sorb -B. For amplification, we used PCR Real -96 SaCycler of V.7.3 "Sacace Biotechnology" and kit As CMV/EBV/HHV-6 TM Real - Time apparatus. The results were analyzed using the standard software SPSS -17 for Windows and EpiInfo-6 -6.

\section{Results}

Of the 198 samples tested, 18 (9.09\%) were positive to at least one of the three viruses, $10(5.10 \%)$ were positive for EBV, 10 (5.10\%) positive for CMV and 12 (6.10\%) positive for HHV -6 . According to age, we found that only those who had a less than or equal to 30 years old were infected. Infection with EBV, CMV and HHV-6 in women accounted for $8.57 \%, 8.57 \%$ and $11.43 \%$ respectively. Against by men, infection rates were low were $4.29 \%$, $3.68 \%$ and $4.90 \%$ for EBV, CMV and HHV -6 . Based on HIV status we found that HIV-positive were more infected than HIV-negative, EBV (12.5\% versus 4.74), CMV (12.5\% versus 4.74$)$, HHV-6 (12.5\% versus 5.79$)$. Seven (7) samples were co- infected EBV/CMV/HHV-6, or $38.89 \%$ of positive samples.

\section{Conclusion}

The prevalence that we recorded is low compared to those reported by previous studies in the sub-region

Labiogene, Ouagadougou, Burkina Faso Attribution License (http://creativecommons.org/licenses/by/4.0), which permits unrestricted use, distribution, and reproduction in any medium, provided the original work is properly cited. The Creative Commons Public Domain Dedication waiver (http:// creativecommons.org/publicdomain/zero/1.0/) applies to the data made available in this article, unless otherwise stated. 